\title{
Effect of Lime on the Compaction and Strength Behaviour of Red Earth treated with Mine tailings
}

\author{
H.N.Ramesh ${ }^{1}$, A.J.Krishnaiah ${ }^{2}$, M.D.Supriya ${ }^{3}$ \\ ${ }^{1,2,3}$ (Department of Civil Engineering, University Visvesvaraya College of Engineering, J.B.Campus, \\ Bangalore University, Bangalore-560056, India)
}

\begin{abstract}
Mine tailings is an industrial by-product obtained from mining industry. The effective disposal of mine tailings(MT) is a great challenge to both civil engineers and mining engineers. On the other hand red earth $(R E)$ is a non expansive soil which is having kaolinite as primary clay mineral and it is a natural soil available in vast areas of India, and also in Karnataka. In the present investigation an attempt has been made to improve the engineering properties of red earth by using mine tailings. The mine tailings properties were studied and treated with red earth soil in the presence of optimum lime content. Unconfined compressive strength tests were conducted to evaluate the engineering properties of the soil samples. The increase in strength due to long term pozzolanic reaction of the calcium oxide present in mine tailings with red earth resuling in the flocculation of particles. This encourages the effective utilization of Mine tailings for Geotechnical applications.
\end{abstract}

Keywords - Mine tailings, Maximum dry density, Optimum moisture content, Pozzolanic reaction, Strength

\section{INTRODUCTION}

Red earth soil is a non-expansive soil having kaolinite as primary clay mineral and it is a natural soil available in vast areas of India and also in Karnataka. Mine tailings is an industrial by-product which is produced in huge quantity from mining industries after extraction of minerals from pyretic ores and poses grave disposal problems. It is also creating environmental hazard. in recent years there is an increase in trend to utilize the mine tailings for geotechnical applications, provided they are treated with some admixtures. Hence, an attempt has been made in this investigation to utilize the mine tailings for geotechnical applications with the addition of some stabilizing agents. Stabilization is found to be one of the effective methods to improve the engineering properties of soils. Mine tailings can be effectively utilized for civil engineering constructions which will minimize the disposal problems and reduce the environmental hazards [Pebble Project, 2005]1. Dhawan et al [1988]2, have investigated that strength development of soil-lime mixtures depends to a great extent on the fine fraction in soils, the fine fraction passing through 425 micron BIS sieve, is responsible for improvement of strength. Broderick and Daniel [1990]3, have found that Red Earth soil treated with lime or cement improve their engineering properties. Ergin et al [1986]4, investigated that addition of lime in EtibankUludag tungsten mine tailings in Turkey resulted in significant improvement of strength with curing periods. Shivapullaiah et al [2003]5, found that addition of bentonite mixtures with lime or cement improve the Geotechnical properties of Red Earth. Shivapullaiah and Lakshmikanth [2005]6, have investigated that addition of $20 \%$ bentonite and $1 \%$ lime by weight of red soil was effectively used for construction as liner material. Soosan et al [2005]7, investigated that the addition of quarry dust to two different cohesive soils viz. kaolinite and Cochin marine clay resulted in the improvement of compaction characteristics and CBR values. Thian and Lee [2010]8, studied the effect of plastic fine grained soil of kaolinite clay on over consolidated mining sand and to assess the main factors affecting the mechanical behaviour of the soils subjected to undrained triaxial compression tests resulted in normalized deviator stress decreases with increasing the over consolidated ratio. Surendra Rao et al [2007]9, investigated that the addition of gold mine tailings at different proportion in to ordinary Portland cement, Black cotton soil and Red soil for manufacturing of cement-tailings bricks and soiltailings bricks resulted in increase in the compressive strength and reveals that soil-tailings are more economical than cement-tailings bricks.

\subsection{Materials}

\section{MATERIALS AND METHODS}

\subsubsection{Red Earth}

The soil is a typically non-expansive clayey soil containing Kaolinite as its chief mineral constituent and was collected at a depth of 1.5 meters below the natural ground surface at the Bangalore University, Jnanabharathi campus, Bangalore, India. To ensure the uniformity of the soil sample it was oven dried, pulverized and sieved through 425 micron BIS sieve before used in the present investigation. 


\section{Effect of Lime on the Compaction and Strength Behaviour of Red Earth treated with Mine tailings}

\subsubsection{Mine tailings}

Mine tailings was collected from an open dump from Kolar Gold Fields (KGF), Kolar, Karnataka, India. After removing the vegetations from the mine tailings, it was air dried, pulverized and passing through 425 micron BIS sieve was used in the present investigation.

\subsubsection{Lime}

Lime $\left[\mathrm{Ca}(\mathrm{OH})_{2}\right]$ used in the present investigation was obtained from Fisher Scientific Chemicals private limited, Mumbai, India.

The physical properties of Red Earth and Mine tailings are presented in Table 1 and the chemical analysis of red earth and mine tailings were carried out by adopting the standard procedures as per the text book of Soil Chemical Analysis by P.R.Hesse published by Chemical Pub. Co.[1972]10. University of Michign, and are presented in Table 2 and 3 respectively.

Table 1. Physical properties of Red Earth and Mine tailings.

\begin{tabular}{|c|l|l|}
\hline \multirow{2}{*}{ Properties } & Values \\
\cline { 2 - 3 } & RE & MT \\
\hline Colour & Brick red & Pale gray \\
\hline Specific Gravity & 2.59 & 2.78 \\
\hline Liquid limit (\%) & 39.3 & 44 \\
\hline Plastic limit (\%) & 26.1 & Non plastic \\
\hline Plasticity Index (\%) & 13.2 & Non plastic \\
\hline Shrinkage limit (\%) & 15.4 & 24.6 \\
\hline Fine sand fraction (\%) & 11.0 & 17 \\
\hline Silt fraction (\%) & 42.0 & 70.4 \\
\hline Clay fraction (\%) & 47.0 & 12.6 \\
\hline Maximum dry density (kN/m $\left.{ }^{3}\right)$ & 16.3 & 15.7 \\
\hline Optimum moisture content (\%) & 20.26 & 21.54 \\
\hline
\end{tabular}

Table 2. Chemical properties of Red Earth and Mine tailings.

\begin{tabular}{|l|l|}
\hline Chemical composition & Percentage \\
\hline Silicon dioxide & 60.4 \\
\hline Alumina & 15.05 \\
\hline Iron oxide & 6.6 \\
\hline Titanium dioxide & 0.2 \\
\hline Calcium oxide & 6.9 \\
\hline Magnesium oxide & 1.7 \\
\hline Potassium oxide & 0.4 \\
\hline Loss on ignition & 8.4 \\
\hline Sodium oxide & 0.3 \\
\hline
\end{tabular}

Table 3. Chemical properties of Mine tailings.

\begin{tabular}{|l|l|l|l|l|l|l|l|l|l|l|l|l|l|}
\hline $\begin{array}{l}\text { Mater } \\
\text { ials }\end{array}$ & $\mathrm{P}^{\mathrm{H}}$ & $\begin{array}{l}\mathrm{SiO}_{2} \\
(\%)\end{array}$ & $\begin{array}{l}\mathrm{Al}_{2} \mathrm{O}_{4} \\
(\%)\end{array}$ & $\begin{array}{l}\mathrm{P}_{2} \mathrm{O}_{5} \\
(\%)\end{array}$ & $\begin{array}{l}\mathrm{K}_{2} \mathrm{O}_{4} \\
(\%)\end{array}$ & $\begin{array}{l}\mathrm{Cu} \\
(\%)\end{array}$ & $\begin{array}{l}\mathrm{Pb} \\
(\%)\end{array}$ & $\begin{array}{l}\mathrm{As} \\
(\%)\end{array}$ & $\begin{array}{l}\mathrm{CN}^{-} \\
(\%)\end{array}$ & $\begin{array}{l}\mathrm{SO}_{3} \\
(\%)\end{array}$ & $\begin{array}{l}\mathrm{SO}_{4} \\
(\%)\end{array}$ & $\begin{array}{l}\mathrm{CaO} \\
(\%)\end{array}$ & $\begin{array}{l}\mathrm{MgO} \\
(\%)\end{array}$ \\
\hline MT & 8.44 & 40.5 & 0.5 & 0.09 & 16.1 & 2.55 & 0.04 & $<$ & $\mathrm{Nil}$ & 0.05 & 0.5 & 14.96 & 6.97 \\
& & & & & 0.01 & & & & & \\
\hline
\end{tabular}

\subsection{Methods}

The compaction tests were conducted using mini compaction test apparatus as per the procedure of Sridharan and Shivapullaiah [2005]11, Unconfined compressive strength tests were carried out as per BIS: 2720 (part X) [1973]12, for various combinations of lime treated red earth with mine tailings. All samples were prepared at their respective maximum dry density and optimum moisture content. The prepared samples were kept in airtight plastic bags and kept in to the desiccators to maintained $100 \%$ humidity for prolong curing periods in such a way that there is no moisture movement. 


\section{RESULTS AND DISCUSSIONS}

\subsection{Compaction}

The compaction tests were carried out for Red Earth alone, Red Earth treated with various percentage of mine tailings, Red Earth treated with mine tailings with the addition of various percentage of lime( 1 to $6 \%$ by weight of soil), the relationship between the maximum dry density and optimum moisture content are studied. The dry density and water content for the above combinations have been investigated.

\subsubsection{Dry density and water content relationship of Red Earth treated with various percentages of mine tailings and lime}

The maximum dry density and optimum moisture content of Red Earth and Mine tailings were found to be $16.3 \mathrm{kN} / \mathrm{m}^{3}$ and $20.26 \%, 157 \mathrm{kN} / \mathrm{m}^{3}$ and $21.54 \%$ respectively. The Compaction tests were carried out with the addition of various percentages of mine tailings to red earth, maximum dry density of Red Earth increases with increase in optimum moisture content as shown in Fig. 1 and Table 4. Further addition of lime (1 to 6\% by weight of soil) to red earth treated with optimum mine tailings, the maximum dry density decreases with increase in the optimum moisture content. The additions of lime due to flocculation of clay particles resist the compactive effort, (Udayashankar and Puranik [2012]13), and is as shown in Fig. 1, 2 and Table 4, 5.

\subsection{Unconfined compressive strength}

The unconfined compressive strength of Red Earth treated with various percentage of mine tailings, Red Earth treated with optimum percentage of mine tailings with various percentage of lime have been studied with curing periods, and the results were analyzed.

\subsubsection{Unconfined compressive strength of Red Earth treated with various percentages of mine tailings}

The Unconfined Compressive Strength of red earth and mine tailing alone are $145 \mathrm{kPa}$ and $130 \mathrm{kPa}$ respectively. With the addition of various percentages of mine tailings to red earth soil, the strength of Red Earth increases for both immediate testing as well as with curing periods. Strength increases up to $10 \%$ addition of mine tailings to red earth, thereafter strength marginally decreases. The decrease in the strength of red earth beyond $10 \%$ addition of mine tailings may be due to weak bonding between the soil particles with mine tailings or due to increase in diffuse double layer thickness, thereby leading to a decrease in strength. Hence, $10 \%$ of mine tailing to the red earth has been chosen as the optimum percentage (Gray and Lin [1972]14). The variations of strength with the addition of various percentages of mine tailings are as shown in Fig. 3 and Table 6.

\subsubsection{Unconfined compressive strength of Red Earth treated mine tailings with various percentages of} lime

The Red Earth treated with optimum percentage of mine tailings with the addition of 1 to $6 \%$ of lime the unconfined compressive strength increases up to 3\% lime addition, beyond 3\% lime strength of Red Earth decreases. However, the addition of 3\% lime shows the significant increase in the unconfined compressive strength for 30 days curing period compared to other percentages. Strength gain of lime treated red earth with optimum percentage of mine tailings is due to the hydration of lime in presence of water which will liberate the calcium hydroxide ions. The increase in strength for curing period is due to alumina present in mine tailings that will gradually react with calcium ions to form calcium alumina hydrate which involves in hydration and pozzolanic reaction (Mohammed and Anita [1998]15, and Mohammed et al [2001] 16). The variation of unconfined compressive strength of Red Earth treated with optimum percentage of mine tailings with the addition of various percentage of lime is as shown in Fig 4 and Table 7.

IV. FIGURES AND TABLES

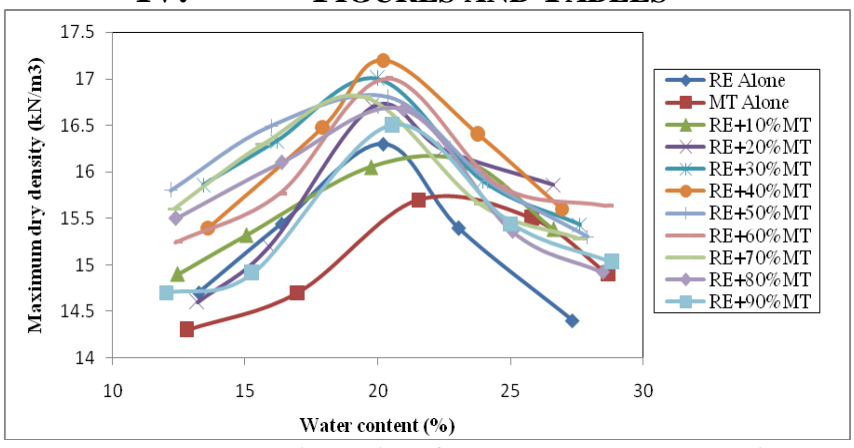

Fig 1. Dry density -water content relationship of Red Earth treated with various percentage of mine tailings 


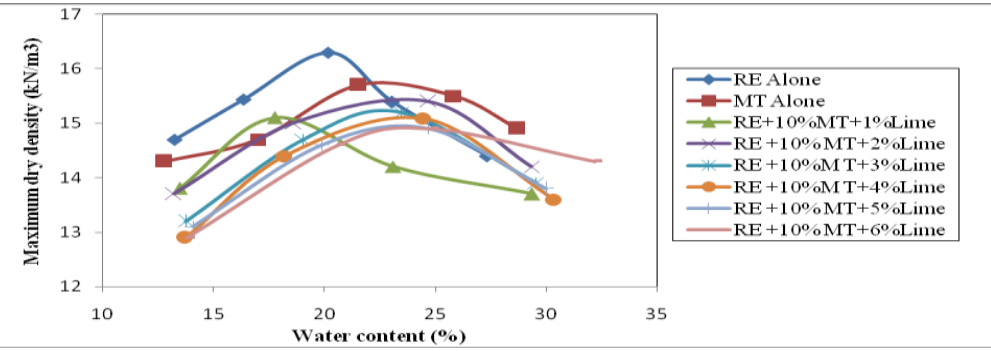

Fig 2. Dry density - water content relationship of optimum mine tailings treated Red Earth with various percentage of lime

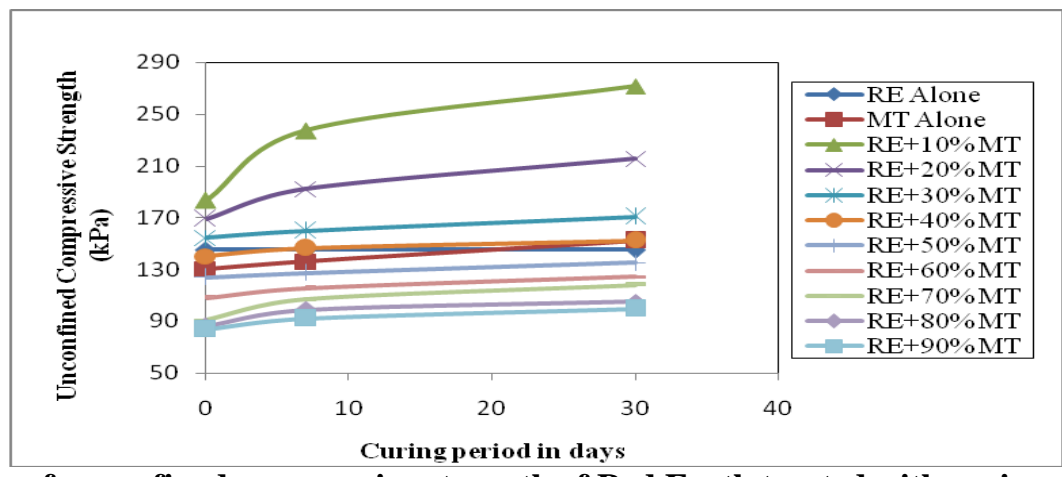

Fig 3.Variation of unconfined compressive strength of Red Earth treated with various percentages of mine tailings for different curing periods

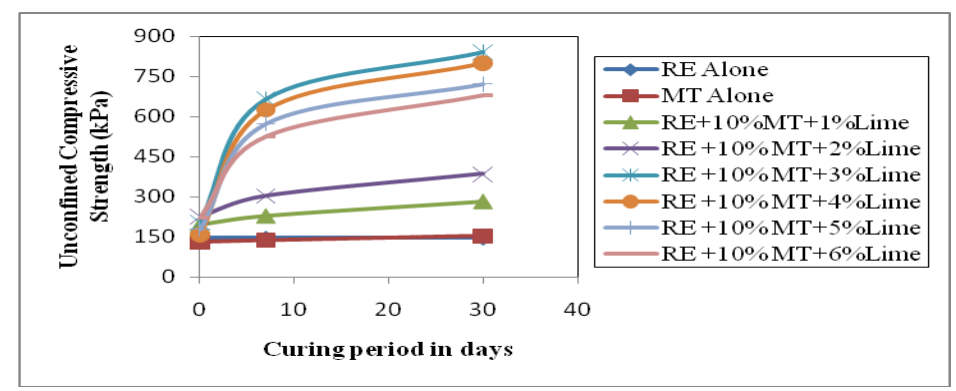

Fig 4. Variation of unconfined compressive strength of mine tailings treated Red Earth with various percentages of lime for different curing periods

Table 4. Compaction Characteristics of Red Earth treated with various percentage of Mine tailings

\begin{tabular}{|l|l|l|}
\hline Mixtures & MDD $\left(\mathbf{k N} / \mathbf{m}^{\mathbf{3}}\right)$ & OMC $(\%)$ \\
\hline RE Alone & 16.3 & 20.2 \\
\hline MT Alone & 15.7 & 21.5 \\
\hline $\mathrm{RE}+10 \% \mathrm{MT}$ & 16.1 & 23.43 \\
\hline $\mathrm{RE}+20 \% \mathrm{MT}$ & 16.6 & 21 \\
\hline $\mathrm{RE}+30 \% \mathrm{MT}$ & 16.8 & 19.5 \\
\hline $\mathrm{RE}+40 \%$ MT & 17 & 20.3 \\
\hline $\mathrm{RE}+50 \%$ MT & 16.8 & 20.2 \\
\hline $\mathrm{RE}+60 \%$ MT & 17 & 20 \\
\hline $\mathrm{RE}+70 \% \mathrm{MT}$ & 17 & 20.2 \\
\hline $\mathrm{RE}+80 \% \mathrm{MT}$ & 16.7 & 19.8 \\
\hline $\mathrm{RE}+90 \% \mathrm{MT}$ & 16.1 & 23.4 \\
\hline
\end{tabular}


Effect of Lime on the Compaction and Strength Behaviour of Red Earth treated with Mine tailings Table 5. Compaction Characteristics of Mine tailings treated Red Earth with various percentage of Lime

\begin{tabular}{|l|l|l|}
\hline Mixtures & MDD $\left(\mathbf{k N} / \mathbf{m}^{3}\right)$ & OMC (\%) \\
\hline RE Alone & 16.3 & 20.2 \\
\hline MT Alone & 15.7 & 21.5 \\
\hline RE+10\%MT+1\%Lime & 15.1 & 17.76 \\
\hline RE +10\% MT+2\%Lime & 15.4 & 24.7 \\
\hline RE +10\%M T+3\%Lime & 15.2 & 23.45 \\
\hline RE +10\%M T+4\%Lime & 15.05 & 24.46 \\
\hline RE +10\% MT+5\%Lime & 14.9 & 24.7 \\
\hline RE +10\% MT+6\%Lime & 14.9 & 24.82 \\
\hline
\end{tabular}

Table 6. Unconfined Compressive Strength of Red Earth treated with various percentage of Mine tailings

\begin{tabular}{|l|l|l|l|}
\hline \multirow{3}{*}{ Mixture } & \multicolumn{4}{|l|}{ UCS Strength (kPa) } \\
\cline { 2 - 4 } & Curing Periods in days & \multicolumn{2}{l|}{} \\
\cline { 2 - 4 } & $\mathbf{0}$ & $\mathbf{7}$ & $\mathbf{3 0}$ \\
\hline RE Alone & 145.0 & $145 ; 0$ & 145.0 \\
\hline MT Alone & 130.2 & 136.6 & 152.2 \\
\hline RE+10\%MT & 183.3 & 237.0 & 271.52 \\
\hline RE+20\%MT & 169.1 & 192.0 & 215.4 \\
\hline RE+30\%MT & 154.3 & 160.0 & 170.54 \\
\hline RE+40\%MT & 140.2 & 146.3 & 152.2 \\
\hline RE+50\%MT & 123.7 & 127.2 & 135.2 \\
\hline RE+60\%MT & 108.0 & 115.5 & 124.2 \\
\hline RE+70\%MT & 90.7 & 106.8 & 118.2 \\
\hline RE+80\%MT & 86.2 & 98.7 & 105.2 \\
\hline RE+90\%MT & 83.7 & 92.1 & 99.5 \\
\hline
\end{tabular}

Table 7. Unconfined Compressive Strength of Mine tailings Treated With Various Percentages of Lime

\begin{tabular}{|l|l|l|l|}
\hline \multirow{3}{*}{ Mixture } & \multicolumn{4}{l|}{ UCS Strength (kPa) } \\
\cline { 2 - 4 } & \multicolumn{4}{l|}{ Curing Periods in days } \\
\cline { 2 - 4 } & $\mathbf{0}$ & $\mathbf{7}$ & $\mathbf{3 0}$ \\
\hline RE Alone & 145 & 145 & 145 \\
\hline MT Alone & 130.2 & 136 & 152.2 \\
\hline RE+10\%MT+1\%Lime & 194.8 & 228.4 & 282.7 \\
\hline RE +10\% MT+2\%Lime & 226.3 & 303.8 & 385.2 \\
\hline RE +10\% MT+3\%Lime & 201.2 & 664.8 & 840.4 \\
\hline RE +10\% MT+4\%Lime & 157.9 & 625.2 & 800.2 \\
\hline RE +10\% MT+5\%Lime & 177.9 & 573.1 & 720.7 \\
\hline RE +10\% MT+6\%Lime & 221.1 & 524.7 & 678.6 \\
\hline
\end{tabular}

\section{CONCLUSION}

Based on the above results, the following conclusions are drawn Maximum dry density decreases and optimum moisture content increases for the Red Earth treated with mine tailings. The same trend was observed for the addition of various percentage of lime to the Red Earth treated with optimum percentage of mine tailings. The unconfined compressive strength of Red Earth increases with the increase in the addition of mine tailings. However, the strength increase is found to be maximum with $10 \%$ addition of mine tailings with and without curing, which is considered as optimum percentage. The unconfined compressive strength of Red Earth treated with optimum percentage of mine tailings increases further with the addition of various percentage of lime with and without curing due to pozzolanic reaction. The increase in strength with the addition of $3 \%$ lime is treated as the optimum percentage. From the present study, it has been concluded that mine tailings can be effectively used for lime stabilization of soils. The use of mine tailings for the geotechnical application will minimize the disposal problem and reduce the environmental hazards. 


\section{References}

[1] Pebble Project, Tailings and Tailings Managements, Northern Dynasty Mines Inc., 2005, 1-4

[2]. P.K.Dhawan, O.P.Bhatnagar and R.K.Swamy ,Design of Soil-lime mixes and the durability aspects- A new approach, HighwayReseaechBulletin(IRC)36,1998,13-25

[3]. G.P.Broderick and D.E.Daniel, Stabilization compacted clay against chemical attack, ASCE, Journal of Geotechnical Engineering.116, 1990, 1549-1567

[4]. Ergin Arioglu, Ali Yuksel and Agrali, Strength characteristics of lime-stabilized mine tailings, Mining Science and Technicalogy3,1986,161-166

[5]. P.V.Shivapullaiah, H. Lakshmikanth and K.Madhukiran, Geotechnical Properties of Stabilized Indian red earth, GeotechnicalandGeologicalEngineering,21,2003,399-413

[6]. P.V.Shivapullaiah and H.Lakshmikanth, Chemical Compatability of lime Stabilized Indian Red Earth as a Liner Material, SoilandSedimentContamination14,2005,515-526.

[7]. T.Soosan, A. Sridhan, B.Jose and B.Abraham, Utilization of Quqry dust to improve the geotechnical properties of soil in highwayconstruction,Geotechnicaltestingjournal,28(4),2005,391-400

[8]. S.Y.Thian and C.Y.Lee, Effect of Plastic Fines on over Consolidated Mining Sand, ARPN Journal of Engineering and AppliedScience,5(11),2010,6-14

[9]. Surendra Ray, Govinda R. Adhikari and Rama N Gupta, Use of gold mill tailings in making bricks: a feasibility study. Wast management and Research, 25, 2007, 475-482

[10] A Text Book of Soil Chemical Analysis by P.R.Hesse, Published by Chemical Pub. Co., University of Michign, 1972

[11] Sridharan A and Sivapullaiah P. V, Mini compaction test apparatus for fine grained soils, Geotechnical testing Journal, 28(3),2005,1-20.

[12]. BIS 2720 (Part X) (1973). Determination of Unconfined Compressive Strength. Bureau of Indian Standards, New Delhi.

[13] Udayashanka D.Hakari and S.C.Puranic, Stabilization of Black Cotton Soils Using Fly Ash, Hubli-Dharwad Municipal Corporation Area, Karnataka, India, Global Journal of Research in Engineering, 12(2), 1, 20-29

[14] D.H.Gray and Lin Y.K, Engineering Properties of Compacted Fly ash, Journal of Soil Mechanics and Foundation Division, ASC,.9 (4), 1972, 361-377

[15]. A.M.O. Mohamed and H.E.Anita, Geoenvironmental Engineering. Elsevier, Amsterdam, 1998

[16]. Mohamed AMO, Hossein M Hassani FP, Ettringite formation in lime remediated mine tailings; III rule of fly ash addition. CIM Bulletin. 2001. 